National Journal of Research in Ayurved Science

\title{
Effect of Virechan Karma in the management of Oligoasthenozoospermia (Shukradushti): A Case Report
}

\author{
Akshata L. Tare*1, Tanuja Gaikwad ${ }^{2}$
}

1. PG Scholar,

2. Guide and HOD,

Panchakarma Dept., L. K. R. A. M. C., Gadhinglaj, Kolhapur, Maharashtra.

*Corresponding author: attare747@gmail.com; Phone No.: 7387456333.

\begin{abstract}
:
Background : Low sperm count (oligozoospermia) and reduced motility of sperms (asthenozoospermia) is the main causes of male infertility and it is correlated with Shukrdushti ( Vitiation of sperms) and is a problem of global proportions. Worldwide infertility is affecting on an average $8-12 \%$ of couples. Infertile men may higher risk of developing other health problems such as diabetes, heart diseases and substance abuse disorders. Ayurveda advocated that, to produce a progeny four things are necessary i.e. Ritu (Reproductive age and ovulation period), Kshetra(Female reproductive tract), Ambu(nutritional factors) and Bija (Sperm and ovum). If there is Dushti (disturbance) in any one of the above factors it would lead into infertility. The modern medical field has now started realizing its importance and a new branch known as Andrology has been developed recently which is still in the progress of producing a satisfactory management for the current problem.
\end{abstract}

Virechana (medically induced purgation) is one among the five cleansing procedure described in Ayurveda which is said to be beneficial in reliving the disturbances of Dosha (bodily humour) $\&$ Dhatus (body tissue). Shukra being on among the seven Dhatus, Virechana has a significant potential to relieve the Vitiation/disturbances in it.

Aim: To access the efficacy of Virechana in the management of Oligoasthenozoospermia.

Materials \& methods : The present case study is upon a 35 years old, dignosed case of oligoasthenozoospermia who attended the Panchakarma OPD at Late Kedari Redekar Ayu Mah Gadhinglaj,Kolhapur. Virechana was done as per the classical method. Assessment was done after Virechana and after 15 days of follow up.

Results : The sperm analysis showed an increase of Total sperm count from 01 million/ml to 68 million/ml. 
Conclusion: Virechana procedure has shown an effective and safe method of increasing the sperm count to a significant level along with the increase in sperm motility. Hence the therapy might may be of significant benefits in patients suffering from oligoasthenozoospermia.

Keywords : Shukradushti, Virechana, Oligoasthenozoospermia

Materials and methods :

Case report : A 35 year old, dignosed case of oligoasthenozoospermia patient attended OPD of Panchakarma, Late Kedari Redekar Ayu Mah Gadhinglaj, Kolhapur with his semen analysis report and complained of failure to conceive since last 7 years. Their active marriage life was 8 years. His semen analysis Administration for Virechana Karma report showed only single sperm count and $100 \%$ non-motile sperms while as semen quantity was sufficient. He had no any major illness in past. No any drug history or family history related this was found. The patient was dignosed as oligoasthenozoospermia and shukradushti as per Ayurveda on the basis of semen analysis report.

Virechana karma was done as per classics and assessments was done after virechana and after 15 days of follow up.

Treatment plan : Virechana karma was carried out as per classics method prescribed in table 1 and virechana yoga was administered as per mentioned in table 2 .

Table-1: Method of Drug

\begin{tabular}{|c|c|c|c|c|c|}
\hline Sr no. & Treatment & Drug used & Dose & Anupana & Duration \\
\hline 1 & $\begin{array}{l}\text { Dipana- } \\
\text { Pachana }\end{array}$ & Nagkeshar Churna & $2 \mathrm{gm} \mathrm{TDS}$ & $\begin{array}{ll}\text { Luke warm } \\
\text { water }\end{array}$ & 3 days \\
\hline 3 & Snehapana & Phalaghruta & $\begin{array}{l}\text { Vardhamana } \\
\text { matra }\end{array}$ & $\begin{array}{l}\text { Luke warm } \\
\text { water }\end{array}$ & 5 days \\
\hline 4 & $\begin{array}{l}\text { Sarvanga } \\
\text { Abhyanga- } \\
\text { Bashpa } \\
\text { Swedana } \\
\end{array}$ & $\begin{array}{l}\text { Bala oil for } \\
\text { Abhyanga }\end{array}$ & $15 \mathrm{ml}$ & - & 3 Days \\
\hline 5 & $\begin{array}{l}\text { Virechana } \\
\text { Karma }\end{array}$ & $\begin{array}{l}\text { DrakshaAaragvadh } \\
\text { kwatha } \\
\text { Eranda Tail }\end{array}$ & $\begin{array}{l}100 \mathrm{ml} \\
30 \mathrm{ml}\end{array}$ & $\begin{array}{l}\text { Luke warm } \\
\text { water }\end{array}$ & 1 Day \\
\hline 6 & \multicolumn{4}{|c|}{ Samsarjana Krama (post diet regimen after Virechana) } & 5 Days \\
\hline & Day 1 & Day 2 & Day 3 & Day 4 & Day 5 \\
\hline Lunch & $\begin{array}{l}\text { Peya (thin } \\
\text { rice soup) }\end{array}$ & $\begin{array}{l}\text { Vilepi (thicker rice } \\
\text { porridge) }\end{array}$ & $\begin{array}{l}\text { Akrita yusha } \\
\text { (Boiled } \\
\text { green grams } \\
\text { prepared } \\
\text { without } \\
\text { spices and } \\
\text { salt) }\end{array}$ & $\begin{array}{l}\text { Krita yusha } \\
\text { (Boiled green } \\
\text { grams } \\
\text { prepared with } \\
\text { spices and } \\
\text { salt, andeaten } \\
\text { with } \\
\text { fermented }\end{array}$ & $\begin{array}{l}\text { Krita } \\
\text { yusha } \\
\text { (Boiled } \\
\text { green } \\
\text { grams } \\
\text { prepared } \\
\text { with spices } \\
\text { and salt, }\end{array}$ \\
\hline
\end{tabular}




\begin{tabular}{|l|l|l|l|l|l|} 
& & & & vegetables $)$ & $\begin{array}{l}\text { andeaten } \\
\text { with } \\
\text { fermented } \\
\text { vegetables })\end{array}$ \\
\hline Dinner & Peya & Vilepi & Akrita yusha & Krita yusha & $\begin{array}{l}\text { Normal } \\
\text { diet }\end{array}$ \\
\hline
\end{tabular}

Table-2: Virechana Yoga Drugs used for Virechana Karma

\begin{tabular}{|l|l|l|l|l|}
\hline Sr. No. & Name & Botnical name & Family & Part used \\
\hline 1 & Aaragvadh & Cassia Fistula (Linn.) & Fabaceae & Fruit Pulp \\
\hline 2 & Eranda & Ricinus communis (Linn.) & Euphorbiaceae & Seed, Root \\
\hline 3 & Draksha & Vitis vinifera L. & Vitaceae & Fruit \\
\hline
\end{tabular}

Investigations:

Semen analysis: They were done before treatment, after Virechana karma and after 15 days of follow up period.

Follow-Up: after 15 days of Virechana Karma.

\section{Pathyapathya (Dietary Restrictions):}

The patient was strictly advised to follow the restrictions regarding food (Bitter, Sour and Salty foods were avoided) food habits and life style (day- sleep and latenight sleep) especially Sansarjana Krama (Peya, Vilepi, Mudga Yusha).

Assessment Criteria:

Table-3: Physical Examination of Semen
The efficacy of the therapy was assessed before and after treatment on the basis of objective criteria of Semen analysis reports.

Observations \& Results: There was no difference found in Physical examination i.e. consistency, volume and liquefaction time in semen analysis report [Table-3].

There was significant increase found in total spermatozoa i.e. $62 \mathrm{million} / \mathrm{ml}$ after Virechana and $68 \mathrm{million} / \mathrm{ml}$ after follow up of 15 days [Table-4].

\begin{tabular}{|l|l|l|l|l|}
\hline No. & Physical Examination & BT & AT & Follow up \\
\hline 1 & Volume & $2 \mathrm{ml}$ & $2 \mathrm{ml}$ & $2 \mathrm{ml}$ \\
\hline 2 & Consistency & Viscous & Viscous & Viscous \\
\hline 3 & Liquefaction & $20 \mathrm{mins}$ & $20 \mathrm{mins}$ & $20 \mathrm{mins}$ \\
\hline
\end{tabular}

Table-4: Effect on Total Sperm Counts on Semen Analysis

\begin{tabular}{|c|c|c|c|c|}
\hline NO. & Total Sperm Counts & BT & AT & Follow up \\
\hline 1 & $\begin{array}{ll}\text { Total } & \text { Spermatozoa } \\
\text { Counts } & \end{array}$ & $01 \mathrm{million} / \mathrm{ml}$ & 62 million/ml & $68 \mathrm{million} / \mathrm{ml}$ \\
\hline
\end{tabular}


Table-5: Effect on Motility of Sperms on Semen Analysis

\begin{tabular}{|l|l|l|l|l|}
\hline NO. & Motility & BT & AT & Follow up \\
\hline 1 & Rapidly Progressive & $0 \%$ & $30 \%$ & $40 \%$ \\
\hline 2 & $\begin{array}{l}\text { Sluggishly } \\
\text { Progressive }\end{array}$ & $0 \%$ & $40 \%$ & $30 \%$ \\
\hline 3 & Non Progressive & $0 \%$ & $10 \%$ & $15 \%$ \\
\hline 4 & Immotile & $100 \%$ & $20 \%$ & $15 \%$ \\
\hline
\end{tabular}

Major positive difference was found in motility of sperms i.e. rapidly progressive sperms $30 \%$ after Virechana and $40 \%$ at follow up period and immotile sperms showed $20 \%$ after Virechana and $15 \%$ at follow up period which were $100 \%$ immotile before treatment [Table-5].

Table-6: Effect on Abnormal Forms of Sperms on Semen Analysis

\begin{tabular}{|l|l|l|l|l|}
\hline NO. & Defect & BT & AT & $\begin{array}{l}\text { Follow } \\
\text { up }\end{array}$ \\
\hline $\mathbf{1}$ & Head Defect & $9 \%$ & $4 \%$ & $3 \%$ \\
\hline $\mathbf{2}$ & Body Defect & $9 \%$ & $6 \%$ & $2 \%$ \\
\hline $\mathbf{3}$ & Tail Defect & $7 \%$ & $4 \%$ & $2 \%$ \\
\hline
\end{tabular}

\section{DISCUSSION \& CONCLUSION:}

To produce progeny four things is necessary

i.e. Ritu, Kshetra, Ambu and Beeja[11] a nd presence of any Dushti in the above factors will lead into Shukradushti which is the prime cause of infertility. Oligoasthenozoospermia is one of the most prevalent reasons for male infertility in clinical practise. In most of the cases, functional deformity in spermatogenesis is the major reason for oligoasthenozooapermia, which involves either defective mechanism of testosterone or excess production of reactive oxygen specimen or both.[12]Acharya Sushruta has included Kshinashukra(oligozoospermia) under Shukradusti. [13] Here Vata

Dosha along with Pitta undergo vitiation and does disturbance in the normal qualities and quantity of the Shukra Dhatu.[14] As a result of this, Shukravaha

Strotas undergoes Dushti, which debilitate one normal individual from impregnating his life partner, ending in infertility.

Virechana might have effect as Vyadhiviparita

Chikitsa. Acharya have given a list of the various disease conditions (Virechya Vyadhi) where Virechana Karma is ideal to administer as prior choice of therapy. Retodosha is one among Virechya Vyadhis.[16] Samyaka Virechana contributes Indriyasamprasada (cleansing of all senses) and detoxification of body[17]. Acharya Kashyapa has mainly highlighted the role of Virechana on Shukra Dhatu. According to him by the action of Virechana, the function of Shukra increases i.e. Shukra becomes more active. The whole process helps in removing the free radicals (oxidants) 
present in the micro circulatory channels of Shukravaha Srotasa, which interferes with the function of Shukra and by doing so, increases the activity of Shukra(motility).[18] Each and every Samshodhana drug has its own target tissue affinity. Trivit is said Sarvarogahara[19]and it has purgative effect as a part of body cleansing[20]. Eranda Tail is told Yoni Shukra Vishodhana (useful in cleansing vagina and semen) to improve motility and to treat sperm defects [21]. Draksha is Virechanopaga ( adjuvant drug in Virechana) Dravya.[22] It enhances the potency of chief Virechana drug and nullifies its adverse actions. It has properties like Madhura Rasa, Madhura Vipaka, Sheeta Virya, Vatapitta Shamaka Doshagnata and Vrishya Karma[23]. There is Vata-Pitta involvement in Shukradushti. Shukra is Jala

mahabhut (water element) dominant. So in order to increase shukra one has to decrease the Agni mahabhut(fire element) which can be possible through removing vitiated Pitta dosha. Virechana is useful for eliminating vitiated Pitta Dosha, active transformation of Strotasa(micro circulatory channels) and most desirable shukraprocured. This process helps to remove free radicals or oxidants which are present in microcirculatory channels of semen pathway and increase the motility of sperms. Thus the chosen Virechana Yoga might have played a crucial role in disintegrating or loosening the pathology of Oligoasthenozoospermia. Deepana,

Pachana and Shodhana should be given systematically and can get better outcome in the management of Shukradushti

(Oligoasthenozoospermi).

\section{CONCLUSION:}

Panchakarma is an inseparable part of any treatment protocol in Ayurveda. Virechana is an important modality and eminent bio cleansing process for vitiated Pitta Dosha. Through Shodhana, Srotoshudhi (Clearing of channels) can be accomplished. The present case study highlights the efficacy of Virechana Karma and a study on larger sample size could yield a significant statistical results.

\section{REFERENCES:}

1. Chris D. meletis, Jason Barker. Natural ways To Enhance Male Fertility. Alternative and Complementary Therapies.2004;10(1):22-27

2. Myrskylä M, Kohler HP, Billari FC. Advances in development reverse fertility declines. Nature. 2009;460:741

3. Lutz W. Fertility rates and future population trends: Will Europe's birth rate recover or continue to decline? Int J Androl. 2006;29:25-33

4. Sharlip I, Jarow J, Belker A, Lipshultz L, Sigman M, Thomas A, et al. Best practice policies for male infertility. Fertil Steril. 2002;77:873-82

5. Thonneau P, Marchand S, Tallec A, Ferial ML, Ducot B, Lansac J, et al. Incidence and main causes of infertility in ar esident population. Hum Reprod. 1991 Jul;6(6):811-6

6. Mehta RH et al. Prevalence of Oligozoospermia and Azoospermia in male partners of infertile couples from different parts of India. Asian j Androl 2006;8:89-93

7. Bunge RG, Keettel WC, Sherman JK. Clinical use of frozen semen; report of 
four cases. Fertil Steril 1954;5(6):52029

8. Dohle GR, Jungwirth A, Colpi G, Giwercman A, Diemer T, Hargreave TB. European Association of Urology. Guidelines on male infertility. [Internet].

2012. Cited on [15 Jan 2017]: Available

from: http://www.uroweb.org/fileadmi n/user_upload/

Guidelines/13\%20Male\%20Infertility. pdf

9. Agnivesha, Charaka, Dradhabala, Charakasamhita, Vidhyotini Hindi commentary, Chikitsa sthana, Chapter 30,Verse 136-139, edited by Narayana Shashtri, Varanasi: Chaukhambha Bharati Academy 2013; p.860-861

10. Vriddha Jivaka, Vatsya, Hemraja Sharma, Kashyapsamhita, Vidhyotini Hindi Vyakhya, Siddhi Sthana, Chapter 2,Verse 6, edited by Satyapala Bhshagacharya, 3rded. Varansai: Chaukhamba Sanskrit Series;2008, p. 225

11. Sushruta, Dalhana, Sushruta Samhita , NibandhaSamgraha, Shareera Sthana, Chapter 2, Verse 34, edited by Jadavji Trikamji Acharya, 8th ed. Varanasi: Chaukhambha Orientalia ; 2008, p.348

12. Mohammad Eid hammadeh et al, Reactive Oxygen Species and
Antioxident in Seminal Plasma and Their Impact On Male Infertility IJFS, Vol 3 , No 3, Nov-Dec 2009, 87-110

13. Sushruta Samhita of Sushruta edited by Vaidhya Jadavji Trikamji Acharya, Chaukhambha Sanskrit Sanshthan Varanasi, Reprint 2013; Sharira sthana Chapter 2/3; 344

14. Ibidem 13; Sharira Sthana Chapter 2/4; 344

15. Ibidem 9, Sutra sthana Chapter 16/ 17$18 ; 315$

16. Ibidem 9, Siddhisthana Chapter 2/13; 981

17. Ibidem 9, Siddhisthan Chapter $1 / 17 ; 964$

18. Ibidem 10, Siddhi Sthana, Chapter $2 / 6 ; 225$

19. Ibidem 9, Kalpasthana, Chapter 7/6; 917

20. Agnivesha, Charaka, Dradhabala, Charakasamhita, edited by Brahmanand Tripathi, Vol II, Varanasi: Chaukhamba publications; 2007, p. 1159-1160

21. Ibidem 13, Sutra Sthana, Chapter 45/114;205

22. Ibidem 9, Part 1, Sutra sthana, Chapter 4/13;85

23. Bhavaprakasha,

Bhavaprakashanighantu, Vidyotini Hindi Commentary, Aamradi Falavarga.

Cite article:

Effect of Virechan Karma in the management of Oligoasthenozoospermia (Shukradushti): A Case Report Akshata L. Tare, Tanuja Gaikwad Ayurlog: National Journal of Research in Ayurved Science- 2019; (7)(3): 1 to 6 